\title{
Regulating complex contracting: a socio-legal study of decision-making under EU and UK law
}

DOI:

$10.1111 / 1468-2230.12326$

\section{Document Version}

Accepted author manuscript

Link to publication record in Manchester Research Explorer

\section{Citation for published version (APA):}

Aspey, E., \& Craven, R. (2018). Regulating complex contracting: a socio-legal study of decision-making under EU and UK law. Modern Law Review, 81(2), 191-221. https://doi.org/10.1111/1468-2230.12326

\section{Published in:}

Modern Law Review

\section{Citing this paper}

Please note that where the full-text provided on Manchester Research Explorer is the Author Accepted Manuscript or Proof version this may differ from the final Published version. If citing, it is advised that you check and use the publisher's definitive version.

\section{General rights}

Copyright and moral rights for the publications made accessible in the Research Explorer are retained by the authors and/or other copyright owners and it is a condition of accessing publications that users recognise and abide by the legal requirements associated with these rights.

\section{Takedown policy}

If you believe that this document breaches copyright please refer to the University of Manchester's Takedown Procedures [http://man.ac.uk/04Y6Bo] or contact uml.scholarlycommunications@manchester.ac.uk providing relevant details, so we can investigate your claim.

\section{OPEN ACCESS}




\section{Regulating complex contracting: a socio-legal study of decision-making under EU and UK law}

Key words: Public procurement law; Public-Private Partnerships; administrative law; EU law; compliance; discretion; regulation; legal uncertainty; legal risk; legal advice

Abstract: The article evaluates interview data on decision-making under public procurement law using Halliday's analytical model on compliance with administrative law. In this study, unlike other studies on administrative compliance, the decisions faced by public bodies are not routine; they relate to the award of complex, high-value contracts. Two contrasting decisions in the procurement process are discussed: the decision over the choice of procedure at the outset of the process, and the decision over the extent to which the public body should negotiate with the winning bidder towards the end of the process. The article considers the rationales behind decisions, and finds that, although public bodies are generally predisposed to comply, legal uncertainty means the relevance of commercial pressures and challenge risk impact heavily on approaches to compliance, even shaping understanding of what compliant behaviour actually is.

Word count: 12117 (15 065 including footnotes)

\section{A. Introduction}

The Private Financing of public Infrastructure (PFI) in the UK, not least under the Private Finance Initiative, has been the subject of intense political and academic scrutiny. 
Drawing on the literature on compliance with administrative law, this article analyses empirical findings on an aspect of PFI that has received much less attention: the various factors influencing the decision-making of procurement officers in light of the legal regulation of the tendering process. The article utilises Halliday's leading theoretical framework for understanding administrative compliance to evaluate decision-making in the field of PFI procurement. ${ }^{1}$ This empirical study, situated in an area of administrative law - public procurement - that is strikingly different to the welfare decision-making studied by Halliday, sheds new light on the way in which elements interact in the decision-making environment. ${ }^{2}$ In particular, here, the market is especially relevant and can, on occasion, be apparently pitted in direct opposition to legality. The study thus provides insight into the circumstances when, in the face of non-legal forces, like the market, legal compliance will gain/lose traction. The article, also, in studying a regulatory regime heavily reliant upon detailed transparency rules, adds to the literature concerning the limitations of legal rules. ${ }^{3}$

\footnotetext{
${ }^{1}$ S. Halliday, Judicial review and compliance with administrative law (Oxford: Hart, 2004). Alternative theories are provided by: R. Kagan, 'The organisation of administrative justice systems: the role of political mistrust', chapter 7, and M. Hertogh,'Through the eyes of bureaucrats: how front-line officials understand administrative justice', chapter 9, both in M. Adler (ed) Administrative law in context (Oxford: Hart, 2010), 172 and 217

2 The 'battle of the norms' according to Julia Black in J. Black, 'New institutionalism and naturalism in sociolegal analysis: institutionalist approaches to regulatory decision making' (1997) 19(1) Law \& Policy 51, 54 ${ }^{3}$ F. Schauer, Playing by the rules: a philosophical examination of rule-based decision-making in law and in life (Oxford: Oxford University Press, 1991); W. Twining and D. Miers, How to do things with rules (Cambridge: Cambridge University Press, 5 $5^{\text {th }}$ ed, 2010); R. Baldwin, 'Why rules don't work' (1996) 53 MLR 321; J. Black, Rules and regulators (Oxford: OUP, 1997), 217-224
} 
Halliday's analytical model, which, like this study, is rooted in extensive empirical fieldwork, is attractive because of the way in which it accounts for the complexity and fluidity of administrative decision-making. Halliday argues that to understand administrative compliance we must appreciate three elements comprising the administrative realm. ${ }^{4}$ The first of these refers to the 'decision-makers', and concerns decision-makers' legal knowledge, legal conscientiousness and legal competence. ${ }^{5}$ The second, 'the decision-making environment', refers to a space where, to differing degrees, law converges/competes with other normative - social, political and economic influences. ${ }^{6}$ The final element, 'the law', concerns the clarity and consistency of the 'message' in legal texts, court judgments, legislation etc. ${ }^{7}$ Legal compliance will be enhanced the clearer and more consistent this message is. Halliday pictures the above three elements as continuums, upon which, to understand particular decisions, we can place public bodies. Even subtle shifts in positioning on these continuums may alter the dynamic between different elements, potentially affecting compliance. ${ }^{8}$

In this article, the relevant legal regulation mostly derives from the UK's membership of the EU, which regulates procurement of goods, works and services by public bodies 'contracting authorities' - across member states in view of the internal market. ${ }^{9}$ The

\footnotetext{
${ }^{4}$ Halliday, $\mathrm{n} 1$ above, 32

5 ibid, 32 and 164

${ }^{6}$ ibid, 33, chapter 5 and 165

${ }^{7}$ ibid, 34 and 165

${ }^{8}$ ibid, 164

${ }^{9}$ See S. Arrowsmith, 'The purpose of the EU procurement directives: ends, means and the implications for national regulatory space for commercial and horizontal procurement policies' (2012) (14) Cambridge
} 
regulation removes trade barriers, including prohibiting national bias in procurement, and, supporting this objective, detailed procedural rules are in place for awarding contracts. ${ }^{10}$ The scale and complexity of PFI means the process followed to select the winning private partner and to agreeing the terms of the contract is invariably resource intensive and crucial for maximising value for money. In 2004, to adapt to the prevalence of non-traditional contracting models, like PFI, and addressing specific transparency and competition concerns arising from UK practice, a new contract award procedure was introduced: 'Competitive Dialogue' (CD). ${ }^{11}$ This additional regulation gave rise to legal grey areas, and its commercial suitability was contestable. ${ }^{12}$

Yearbook of European Legal Studies 1. In a public referendum on 23 June 2016, UK voters decided in their majority that the country should leave the EU, and on 29 March 2017 the UK Government sought to commence the two-year negotiation period for leaving the EU under Article 50, Treaty on European Union. It is not possible to say at this stage what withdrawal from the EU will mean for the regulation of public procurement in the UK (See S. Arrowsmith, 'The implications of Brexit for public procurement law and policy in the United Kingdom' (2017) Public Procurement Law Review 1)

10 S. Arrowsmith, The law of public and utilities procurement: volume 1 (London: Sweet \& Maxwell Ltd, $3^{\text {rd }}$ ed, 2014)

11 Directive 2004/18/EC of the European Parliament and of the Council of 31 March 2004 on the coordination of procedures for the award of public works contracts, public supply contracts and public service contracts (OJ L 134, 30.4.2004, p. 114-240) (Public Sector Directive 2004), art 29. See S. Arrowsmith, The law of public and utilities procurement (London: Sweet \& Maxwell Ltd, 2nd ed, 2005), chapter 10; Arrowsmith (2014), ibid, chapter 8; S. Arrowsmith and S. Treumer (eds), Competitive dialogue in EU procurement law (Cambridge: CUP, 2012); M. Burnett and M. Oder, Competitive dialogue-a practical guide (Maastricht: European Institute of Public Administration, 2009); P. Trepte, Public procurement in the EU: a practitioner's guide (Oxford: OUP, 2007), 404-409 and 445-453

${ }^{12}$ Arrowsmith (2005), ibid, chapter 10; M. Burnett, 'PPP and EU public procurement reform-time to change the rules on competitive dialogue?' (2011) 6 European Public Private Partnership Law Review 61; S. 
The article, through a compliance lens, analyses empirical findings on decision-making under the legal framework regulating PFI procurement, in place in England and Wales from 31 January 2006 to 26 February $2015 .{ }^{13}$ In so doing, the article examines the factors that lead procurement officers within a contracting authority towards (non-)compliance with the relevant regulations - in particular considering responses to uncertainty and rules that may conflict with legitimate needs. The empirical data was gathered prior to reform of the legal regime in $2014 ;{ }^{14}$ however, the article, in thinking about the way in which the regulation can positively influence the behaviour of authorities, ${ }^{15}$ remains relevant to EU internal market regulation, in particular, because the European

Treumer, 'Competitive dialogue' (2004) PPLR 178; S. Treumer, 'Flexible procedures or ban on negotiations? Will more negotiation limit the access to the procurement market?', chapter 5, in G. Skovgaard Ølykke, C. Risvig Hansen, C. D. Tvarnø (eds) EU public procurement - modernisation, growth and innovation: discussions on the 2011 proposals for public procurement directives (Copenhagen: DJøF Publishing, 2012)

${ }^{13}$ The Public Contracts Regulations 2006, SI No 5 (PCR 2006), superseded by the Public Contracts Regulations 2015, SI No 102

${ }^{14}$ Directive 2014/24/EU of the European Parliament and of the Council of 26 February 2014 on public procurement and repealing Directive 2004/18/EC (OJ L 94, 28.3.2014, p. 65). See Arrowsmith, n 10 above, chapter 8; M. Burnett and M. Oder, Competitive dialogue and negotiated procedures - a practical guide (Maastricht: European Institute of Public Administration, 2015); M. Burnett, “The new rules for competitive dialogue and the competitive procedure with negotiation in Directive 2014/24 - what might they mean for PPP?' (2015) 10(2) EPPPLR 62; R. Caranta, 'The changes to the Public Contract Directives and the story they tell about how EU law works' (2015) 52 Common Market Law Review 391, 450-453; J. Davey, 'Procedures involving negotiation in the new Public Procurement Directive: key reforms to the grounds for use and the procedural rules' (2014) PPLR 103

15 Halliday, n 1 above, 31 
Commission's 2015 Single Market Strategy ${ }^{16}$ draws attention to compliance, including compliance with EU procurement law.

The analysis complements scholarship on legal compliance in the field of administrative justice, though, admittedly, the term compliance is troublesome here. This is because the rules on CD lack clarity to a significant degree and there has been no guidance from the courts, generally making it impossible, even for legal experts, to say with certainty whether or not particular actions are technically compliant with the legal regime. Instead, in line with the language used by participants in the empirical study, the article prefers to talk in terms of legal risk -17 where, generally speaking, a strict interpretation may be equated with low risk behaviour and risk heightening as one departs from this. ${ }^{18}$

The discussion is also informed by insight from other aspects of the compliance literature concerning individual and corporate behaviour. ${ }^{19}$ Research on administrative discretion

\footnotetext{
${ }^{16}$ European Commission, Communication from the Commission to the European Parliament, the Council, The European Economic and Social Committee and the Committee of the Regions: upgrading the Single Market: more opportunities for people and business, COM(2015) 550 final (Brussels, 28 October 2015), 3.2

${ }^{17}$ R. Moorhead and S. Vaughan, Legal risk: definition, management and ethics: executive report (UCL Centre for Ethics and Law, 2015) available at https://www.ucl.ac.uk/laws/law-ethics/research/papers/ercexecutive-report-legal-risk-definition-management-ethics.pdf (last accessed 5 August 2016)

18 See also on risk F. Knight, Risk, Uncertainty and Profit (1921, London: LSE, 1948), Ch.VIII: structures and methods for meeting uncertainty, and more generally G. Gigerenzer, Risk savvy: how to make good decisions (London: Penguin Books, 2015)

${ }^{19}$ L.M. Friedman, Impact: how law affects behaviour (Cambridge, Massachusetts: Harvard University Press, 2016); C. Hodges, Law and corporate behaviour: integrating theories of regulation, enforcement, compliance and ethics (Oxford: Hart, 2015); P. J. May, 'Compliance motivations: perspectives of farmers,
} 
and compliance with administrative law tends to situate itself in 'traditional' legal areas involving 'front line' services ('street level bureaucrats') in which decisions directly impact on individuals and actors are faced with similar decisions on a frequent basis (eg decisions over welfare entitlements). In contrast, here, we find administrative actors in a much more commercial setting - contracting with third parties (invariably the private sector) - and, given CD may only be used for 'complex' contracts, the decisions relate to atypical procurement activity, involving sophisticated, high value contracts rather than routine decisions. In addition, the scale and risk profile of these procurements adds a further element of interest, as the decisions considered in this research were often not down to procurement officers within the relevant authority acting in isolation; ${ }^{20}$ in particular, external legal advisors were privy to the decision-making process, providing advisory support on the different options open and the legal and commercial implications of decisions (section 000). This led to different approaches to legal and non-legal pressures than those normally seen with street-level bureaucrats.

The article begins in section two with an explanation of the legal regime governing public procurement in the EU and UK, and discussion of CD. In section three the research methods are outlined. To explore contrasting experiences, the article then moves on to

homebuilders, and marine facilities' (2005) 27(2) Law \& Policy 317; C. Parker and V. Lehmann Nielsen, Explaining compliance: business responses to regulation (Cheltenham: Edward Elgar, 2011); C. Parker and V. Lehmann Nielsen, 'Compliance: 14 questions', chapter 13, in P. Drahos (ed) Regulatory theory: foundations and applications (Acton, ACT: ANU Press, 2017); T. R. Tyler, Why people obey the law (Princeton: Princeton University Press, 2006)

${ }^{20} \mathrm{H}$. Simon, Administrative behaviour: a study of decision-making processes in administrative organization (1945, New York: Free Press, $4^{\text {th }}$ ed, 1997), 7. See also Halliday, n 1 above, 41 
examine decision-making with respect to two legal grey areas in the CD process: the decision, at the outset, to use CD rather than an alternative procedure; and the decision over the extent to which the authority should negotiate with the winning bidder, including whether or not to allow changes to the winning tender, towards the end of the process. For each of the two grey areas, the discussion is divided under two main headings, drawn from the continuums identified by Halliday: (1) the clarity of the law and, (2) the decision-making environment. It will be seen that the article adds to the literature on administrative law, revealing unfamiliar aspects of legal uncertainty (made vivid because of the financial crisis), which are of broad interest. Legal certainty and clarity of the law is central to the analysis. Deficiencies here can be seen to supress the normative strength of the law.

\section{A. PFI under EU and UK public procurement regulation}

\section{B. Public procurement law: command and control}

Since 1992, and the formal launch of the Private Finance Initiative - introduced to increase the scope for private financing of capital projects - UK governments have continually embraced the PFI model (though the Private Finance Initiative has taken on multiple guises, including Public-Private Partnerships (PPP) and currently Private Finance 2 (PF2)), and it is reported that '[o]ver 700 projects have reached financial close, securing private sector investment of around [55 billion pounds]'.21 The empirical

\footnotetext{
${ }^{21}$ HM Treasury, Private Finance Initiative and Private Finance 2 projects: 2015 summary data (March 2016), 
research presented in this article relates to PFI experience under the 2005-10 Labour Government and 2010-15 Conservative-Liberal Democrat Coalition Government. ${ }^{22}$ This was a turbulent period for the PFI market because, following a spell of relative economic calm and public investment, 2007-08 witnessed the financial crisis (PFI deals are heavily dependent on debt funders, such as banks), developing - through bailouts, recession and stagnation - into a debt crisis (2010 onwards).

During the period of study, many UK PFI contracts, because of their high financial value, would have fallen to be regulated under Directive 2004/18/EC.23 The EU has used 'coordination' directives to supplement general Treaty rules and the principles applicable to procurement in member states since the 1970s. However, the 2004 Directive represented a significant landmark, establishing a detailed and prescriptive body of procedural law in marked contrast to the framework regulation that had gone before. ${ }^{24}$ In keeping with typical 'command and control' regimes, 25 the rules are backed by a

${ }^{22}$ See HM Treasury, Public Private Partnerships: the Government's approach (2000); HM Treasury, PFI: meeting the investment challenge (2003); HM Treasury, PFI: strengthening long-term partnerships (2006); HM Treasury, Infrastructure procurement: delivering long-term value (2008); HM Treasury, A new approach to Public Private Partnerships (2012)

${ }^{23}$ Public Sector Directive 2004, n 11 above. The article does not concern itself with concession arrangements (works and services). The article is also not concerned with utilities PFI procurement ${ }^{24}$ S. Arrowsmith, 'The past and future evolution of EC procurement law: from framework to common code?' (2005-06) 35 Public Contract Law Journal 337

${ }^{25}$ R. Baldwin et al, Understanding regulation (Oxford: OUP, $2^{\text {nd }}$ ed, 2012), 106-111; A. Ogus, Regulation: legal form and economic theory (Oxford: Hart, 2004); K. Yeung, Securing compliance: a principled approach (Oxford: Hart, 2004) 
system of enforcement. ${ }^{26}$ In the UK, High Court litigation by aggrieved suppliers is relied upon as the primary means of enforcement. ${ }^{27}$ In the case of a breach, there is also the possibility of the European Commission bringing proceedings against the UK (rather than an individual contracting authority) before the Court of Justice of the European Union, though this is rare in practice. ${ }^{28}$

In keeping with the UK's traditional approach to regulating procurement, ${ }^{29}$ when transposing the 2004 Directive, the UK government afforded authorities maximum flexibility. For example, the Public Contracts Regulations 2006 (PCR) ${ }^{30}$ entered into force on the deadline for implementation, January 31 2006, adopting a copy-out approach in which little was added to the text of the Directive. ${ }^{31}$ The Directive's ambiguous and complex provisions - the product of intergovernmental negotiations and compromise

${ }^{26}$ Council Directive 89/665/EEC of 21 December 1989 on the coordination of the laws, regulations and administrative provisions relating to the application of review procedures to the award of public supply and public works contracts (OJ L 395, 30.12. 1989, p. 33)

27 PCR 2006, reg 47(6)

28 Treaty on the Functioning of the European Union, art 258; D. Pachnou, 'Factors influencing bidders' recourse to the European Commission to enforce EC procurement law' (2005) PPLR 91

29 Arrowsmith, n 10 above, chapter 3; S. Arrowsmith, 'Implementation of the new EC procurement directives and the Alcatel ruling in England and Wales and Northern Ireland: a review of the new legislation and guidance' (2006) 3 PPLR 86, 87; S. Arrowsmith and R. Craven, 'Competitive dialogue in the United Kingdom', chapter 3, in Arrowsmith and Treumer (eds) (2012), n 11 above, 181, 185

30 PCR 2006, n 13 above. Scotland has its own regulations: the Public Contracts (Scotland) Regulations 2006, SSI No 1, and now the Public Contracts (Scotland) Regulations 2015, SSI No 446

${ }^{31}$ Arrowsmith (2006), n 29 above 
(where the purpose behind the regulation was becoming blurred) ${ }^{32}$ - were effectively transplanted into domestic law. ${ }^{33}$

\section{B. Tailoring award procedures to the PFI era}

Prior to CD's introduction in 2004, the negotiated procedure was used as the standard procedure to procure PFI contracts, ${ }^{34}$ a practice encouraged by UK Government. ${ }^{35}$ This section will outline the origins of $C D$, describing the inadequacies of the pre-2004 regime for PFI procurement.

The negotiated procedure is unstructured with few legal requirements. ${ }^{36}$ Its flexibility means it is commercially attractive for PFI: due to the sophistication of these contracts, at the outset, there will be many variables and uncertainties (eg over risks parties will be prepared to accept or detail on financing), and the legal framework enabled an iterative process in which 'the ideas and capabilities of bidders and the authority's preferences can

\footnotetext{
${ }^{32}$ Arrowsmith, n 9 above

${ }^{33}$ H. Gordon, S. Rimmer and S. Arrowsmith, 'The economic impact of the European Union regime on public procurement: lessons for the WTO' (1998) 21(2) The World Economy 159, 170

34 P. Braun, The practical impact of EU public procurement law on PFI procurement practice in the UK (University of Nottingham, PhD thesis, 2001) available at http://eprints.nottingham.ac.uk/10913/ (last accessed 23 May 2017); P. Braun, 'Strict compliance versus commercial reality: the practical application of EC public procurement law to the UK’s Private Finance Initiative' (2003) 9 European Law Journal 575

35 Treasury Taskforce, Technical note no. 2: how to follow EC procurement procedures and advertise in the OJEC (1998), 3.2

36 Public Sector Directive 2004, art 30; PCR 2006, reg 13 and 17
} 
be tailored to produce the optimum outcome, without excessive procedural costs'. ${ }^{37}$ Freedom to negotiate meant an authority's requirements could evolve to overcome information asymmetries and reflect what the market is able to deliver. It became accepted practice to structure negotiations into bidding rounds, and to use these to whittle down bidder numbers and identify a 'preferred bidder'. 38 For commercially understandable reasons, the deal would then be fleshed out with this one bidder: only one bidder - with certainty of success - needed to incur the substantial costs of negotiating to final agreement. ${ }^{39}$ However, such single bidder negotiations are contentious, especially so the more the final deal looks different to the winning tender. 40

There were misgivings over the way in which the negotiated procedure had come to be treated as the 'go to' for PFI, and the transparency and competitive tension maintained in these processes. ${ }^{41}$ The EU procurement rules indicate a general distrust of negotiations -

\footnotetext{
${ }^{37}$ S. Arrowsmith, 'Public Private Partnerships and the European procurement rules: EU policies in conflict?' (2000) 37 Common Market Law Review 709, 722

38 ibid, 722

${ }^{39}$ ibid, 722

40 'One third of public sector teams made changes to PFI projects after they had selected a single, preferred bidder' (House of Commons Committee on Public Accounts, HM Treasury: tendering and benchmarking in PFI (Sixty-third Report of Session 2006-07) (2007), 5)

41 Office of Government Commerce (OGC), Procurement policy: information note 04/06 - 31 July 2006 : practical guidance on the use of competitive dialogue (2006), 5; OGC, Competitive dialogue procedure: OGC guidance on the competitive dialogue procedure in the new procurement regulations (January 2006), section 2; OGC and HM Treasury, Competitive dialogue in 2008: OGC/HMT joint guidance on using the procedure (2008), section 3.2. The above OGC guidance is now archived at
} 
which may be perceived to lack transparency and mask trade barriers. ${ }^{42}$ Legal rules limited use of the negotiated procedure to specified situations, such as where, in 'exceptional cases', due to the nature of the project, 'prior overall pricing' is not possible ${ }^{43}$ and where 'specifications cannot be established with sufficient precision',44 and the procedure's availability for PFI was, legally, not clear. ${ }^{45}$ The above concerns were brought to the fore when the Commission issued a 'reasoned opinion' against Westminster City Council's use of the negotiated procedure for the PFI redevelopment of a school. ${ }^{46}$

The alternatives to the negotiated procedure (prior to $C D$ ), the open and restricted procedures, are suited to straightforward procurement, and lack the flexibility to enable the sort of iterative process desirable for PFI. For example, these procedures require an authority to be in a position to draw up detailed requirements ('technical specifications') upfront and tenders must conform to these specifications, with little scope for negotiation. ${ }^{47}$

http://webarchive.nationalarchives.gov.uk/20110822131357/www.ogc.gov.uk (last accessed 23 May 2017)

${ }^{42}$ S. Arrowsmith, 'The EC Procurement Directives, national procurement policies and better governance: the case for a new approach' (2002) 27(1) European Law Review 3

43 Public Sector Directive 2004, art 30(1)(b); PCR 2006, reg 13(b)

${ }^{44}$ ibid, art 30(1)(c); reg 13(c)

${ }^{45}$ Its use was, however, accepted in $R$ (on the application of Kathro) $v$ Rhondda Cynon Taff CBC [2001] EWHC Admin 527

${ }^{46}$ European Commission, Single Market News (No 23, October 2000)

${ }^{47}$ Public Sector Directive 2004, art 23; PCR 2006, reg 9 
Introduced in 2004, the rules on CD sought to address the above issues, and, according to OGC guidance, 'lobbying by UK stakeholders, both public and private sector, helped to ensure that the final text fitted better with UK PFI practice'. ${ }^{48}$ The final result was a procedure which the OGC described as 'similar in many ways to the existing practice of letting PFI contracts'. ${ }^{49}$ The approach taken combines some flexibility of the negotiated procedure with the transparency and structure of the restricted procedure. ${ }^{50}$ For example, corresponding with existing practice, there was flexibility in the opening stages of the procedure: an authority does not need to draw up detailed technical specifications upfront, just 'needs and requirements'.51 These 'needs and requirements' may be developed during a 'dialogue stage'. In dialogue, the authority may discuss all aspects of the contract with bidders, and the stage may be structured into bidding phases allowing the authority to reduce numbers as it homes in on its preferred solution/s. ${ }^{52}$ However, the dialogue stage must be formally brought to a close ${ }^{53}$ and it is at this point that the procedure tightens and distrust of negotiations resurfaces: the authority must hold a final competitive tendering round, ${ }^{54}$ and, representing an abrupt departure from previous common practice in the UK under the negotiated procedure, from this point scope for any further dialogue/negotiation is tightly curtailed (see section 000 below). ${ }^{55}$ This

\footnotetext{
48 OGC (January 2006), n 41 above, 1.2

49 ibid, 1.2

50 Public Sector Directive 2004, recital 31

51 ibid, art 29(2);PCR 2006, reg 18(5)

52 ibid, art 29(4); reg 18(6)

53 ibid, art 29(5); reg 24

${ }^{54}$ ibid, art 29(6); reg 25(b)

55 ibid, art 29(6) and (7) (para 2); reg 26 and 28
} 
requirement for complete final tenders and restrictions on post-tender negotiations was contentious and the reforms highlighted a tension between the different aims of procurement regulation at the EU and domestic levels. The limitation on negotiation was intended to enhance transparency for the benefit of the internal market but potentially stood to jeopardise domestic interests in ensuring efficiency and value for money in procurement (see, for example, the requirements set out in local government's best value duty) ${ }^{56}$ Efficiency and value for money are arguably outside the EU's competence and therefore not appropriate to consider at the EU level. ${ }^{57}$ This clash between the aims of the EU and domestic regimes added to the lack of clarity for authorities in deciding upon appropriate responses under the law, and was instrumental in the decision-making seen below.

\section{A. Method}

Data gathering and analysis in this empirical study of the operation of the legal rules on CD was completed in 2012. 58 semi-structured interviews were carried out between January 2010 and March 2011. This included 41 interviews with legal advisors in private practice representing different solicitors' firms; these individuals and firms were selected due to their experience of PFI procurement advisory work. ${ }^{58}$ In order to capture a complete range of experiences and perspectives, further interviews were carried out with

\footnotetext{
56 Local Government Act 1999

${ }^{57}$ Arrowsmith, n 9 above, 37-38

${ }^{58}$ These participants were identified using Chambers and Partners UK guide (available at http://www.chambersandpartners.com/guide/uk/1) and law firms' websites.
} 
procurement officers and public sector in-house legal advisors with experience of CD procurement (14 interviews), and policymaking organisations responsible for overseeing the implementation of $\mathrm{CD}$, across the UK generally and with respect to particular PFI programmes (three interviews).

Previous empirical work on PFI procurement ${ }^{59}$ had assumed that external legal advice was invariably sought on the conduct of a PFI procurement. To clarify this point a scoping survey was carried out over telephone immediately prior to the main fieldwork, involving a proportion of authorities advertising CD procurements in 2008 (282 different authorities). The survey confirmed the central role played by external legal advisors. This was because, as later explained in interviews, procurement of these large scale and complex projects is not a common occurrence for many authorities - so there is a lack of familiarity with such procurement - and these significant procurements carry a 'risk profile' that warrants specialist assistance.

The approach to the use of legal advice was not completely uniform: some authorities were heavily dependent on external lawyers, where lawyers would be required to 'hold... the authority's hand' through the process, and others, eg with more experience, were confident enough to use external legal expertise as and when needed or not at all. Legal advisors confirmed that, in situations where advice was sought, the authority would be given the decision-making options, the pros and cons (legal, practical and commercial) for each option, and recommendations suited to the particularities of the situation. It was stressed that the final decision was always the authority's, though legal advisors

\footnotetext{
${ }^{59}$ Braun (2003), n 34 above, 578
} 
confirmed that, overwhelmingly, their recommendations were followed. Where this was not the case, it would often be put down to the individual characters involved, though legal advisors were not always well positioned to fully appreciate the decision-making environment. ${ }^{60}$ For example, procurement officer 8's reasons for a risk averse approach centred around the sanction provided by a successful, high profile legal challenge some years prior:

My remit, number one, there will be no successful legal challenges. Everything else is subsidiary to that. My position is down to the fact that we lost a court case ... Since then, the authority has been very conscious of its reputation. It is incredibly embarrassing ... We are quite a vulnerable buying authority, high profile enough that if someone wins a case against us it is going to make the papers

Individuals and organisations were given assurances that participation would be anonymous and confidential information would not be disclosed. Most interviews were digitally recorded (handwritten notes were taken in four interviews) and transcribed, and data was coded using computer software, NVivo. ${ }^{61}$ Codes were determined under a data-driven, grounded theory, approach. ${ }^{62}$

\section{A. The reality of competitive dialogue}

\footnotetext{
${ }^{60}$ Halliday, $\mathrm{n} 1$ above, 102

${ }^{61}$ http://www.qsinternational.com/nvivo-product (accessed 10 April 2017)

${ }^{62}$ A. Strauss and J. Corbin, Basics of Qualitative Research Techniques and Procedures for Developing Grounded Theory (Thousand Oaks, Calif: SAGE Publications, $2^{\text {nd }}$ ed, 1999)
} 


\section{B. Introduction}

$\mathrm{CD}$, in seeking to better delineate acceptable conduct for procuring PFI, highlights the inherent limitations of regulating by way of detailed legal rules. ${ }^{63}$ This investigation, in placing particular focus on clarity in the law, highlights how clarity may be undermined not simply by the imprecise drafting of specific rules, ${ }^{64}$ but by, for example, the nature of the regulation - here, its supra-national nature - and the surrounding circumstances. Sections 000 and 000 below look at two grey areas in which legal rules must be interpreted and applied: the choice of CD as award procedure ('grey area one'), and the scope for negotiations with the preferred bidder (ie the winner) following the final tendering stage and contract award ('grey area two'). ${ }^{65}$ As per the Halliday model, a range of factors shape interviewees' understanding of the legal rules and the decisions made when applying that understanding. Particularly important factors were soft law in

63 Baldwin, n 3 above; Black, n 3 above, 217-224

64 J. E. Calfee and R. Craswell, 'Some effects of uncertainty on compliance with legal standards' (1984) 70 Virginia Law Review 965; R. Craswell and J. E. Calfee, 'Deterrence and uncertain legal standards' (1986) 11(2) Journal of Law, Economics and Organization 279; A. Hopkins, 'Compliance with what: the fundamental regulatory question' (Autumn 1994) 34(4) British Journal of Criminology 431; I. MacNeil, 'Uncertainty in commercial law' (2009) 13(1) Edinburgh Law Review 68; D. McBarnet and C. Whelan, 'The elusive spirit of the law: formalism and the struggle for legal control' (1991) 54(6) MLR 848; M. Raymond, 'Regulatory compliance with costly and uncertain litigation' (2004) 26(2) Journal of Regulatory Economics 165 65 See Arrowsmith and Craven (2012), n 29 above. In 2010, the government published a review of practice: HM Treasury, HM Treasury review of competitive dialogue (November 2010) 
relation to the first grey area (section 000) and commercial pressures, including, for grey area two, the impact of the financial crisis (section 000).

\section{B. Grey area one: choosing to procure under competitive dialogue}

\section{Background}

The PCR 2006 provides that CD is available where a contract is 'particularly complex' and 'the use of the open and restricted procedure will not allow for the award of the contract'.66 The drafting leaves much uncertainty. ${ }^{67}$ In particular, there was a lack of clarity in relation to the implications of CD's introduction on the availability of the negotiated procedure (the wording of the grounds for which saw no changes) - ie when can an authority choose to use the negotiated procedure over CD? Uncertainty also surrounded the degree of complexity required - ie how complex does a contract need to be to use CD instead of the restricted procedure? Responses to these two aspects of uncertainty are discussed below. The Commission position viewed CD as the replacement for the negotiated procedure for most PFI-type deals. ${ }^{68}$ For example, the Commission clarifies that complexities, whether financial and/or legal, 'arise very, very often in

\footnotetext{
${ }^{66}$ PCR 2006, reg 18(2)

${ }^{67}$ Note the different wording used in recital 31 and arts 1(11)(c) and 29(1), Public Sector Directive 2004. This suggests disagreement over the procedure's availability (S. Treumer, 'The field of application of competitive dialogue' (2006) PPLR 307, 314)

${ }^{68}$ European Commission, Explanatory note-competitive dialogue-classic directive (2005) (CC/2005/04_rev 1 of 5.10.2005)
} 
connection with ... [PPPs]'.69 There was no comment on the role envisaged for the negotiated procedure.

CD's introduction had a dramatic impact on UK PFI procurement practice: it quickly became the standard procedure for PFI, replacing the negotiated procedure. The UK, alongside France, was one of the heaviest users of the procedure, with 1,380 notices specifying CD as the intended award procedure (January 2006 - December 2009). ${ }^{70}$ The figures dwarf numbers from other member states, like Germany (131 notices). ${ }^{71}$ In line with the high UK uptake, use of the negotiated procedure dropped off markedly. Indeed, according to interviewees, the negotiated procedure was 'dead in the water' (Lawyer 26), 'completely ignored' (Lawyer 30), and 'may as well not be [part of the legal framework]' (Lawyer 2). This response occurred despite the lack of clarity in the law appearing to provide some incentive for sticking with the known quantity of the negotiated procedure. ${ }^{72}$ Overall, the extent to which authorities departed from (the still available) negotiated procedure, following the introduction of $\mathrm{CD}$, signals that some were applying the rules on procedure availability in a risk averse manner and there was practice (complete avoidance of the negotiated procedure) that went beyond standard compliance, something classical deterrence theories struggle to account for (see

\footnotetext{
69 ibid, 3

${ }^{70}$ S. de Mars and R. Craven, 'An analysis of use of competitive dialogue in the EU' chapter 2 in Arrowsmith and Treumer (2012), n 11 above, 152

${ }^{71}$ ibid, 152

${ }^{72} \mathrm{~A}$. Brown, "The impact of the new directive on large infrastructure projects: competitive dialogue or better the devil you know?' (2004) PPLR 160
} 
below). ${ }^{73}$ Despite disquiet about the appropriateness of CD for PFI (eg in relation to whether the latter stages of the procedure are sufficiently flexible), ${ }^{74}$ coupled with a perceived low risk of sanction for choosing the negotiated procedure, CD became the procedure of choice for PFI. The sections below will consider potential explanations for the low risk approach to this decision.

\section{Clarity of the law}

A crucial factor under Halliday's model is the clarity and consistency of the relevant legal rules. In assessing the availability of $\mathrm{CD}$, as noted above, the key issue for the authority and its legal advisors was the meaning of 'complexity'. Absent any case law, there remained a lack of clarity on this point for the procurement officers who had to make the decision on which procedure to use. Uncertainty in the law such as this can often lead to those affected turning to 'soft law'75 to fill in the gaps in the legal regulation. ${ }^{76}$

Non-enforceable advice and guidance has long been used in the UK regulation of public procurement and is recognised as a means of 'steering entities towards a particular

\footnotetext{
${ }^{73}$ See J. Scholz, 'Enforcement policy and corporate misconduct: the changing perspectives of deterrence theory' (1997) 60 Law and Contemporary Problems 253; N. Gunningham and R. A. Kagan, 'Regulation and business behaviour' (2005) 27(2) Law \& Policy 213

${ }^{74}$ HM Treasury (2010), n 65 above, 3.38

75 On the role of guidance from regulators as a supplement to principles-based regulation see Black, n 3 above, 124. Also, see generally, C. Harlow and R. Rawlings, Law and administration (Cambridge: CUP, $3^{\text {rd }}$ ed, 2009), 190-195; G. Weeks, Soft law and public authorities (Oxford: Hart, 2015)

76 MacNeil, n 64 above, 83-84
} 
interpretation or in giving them confidence in applying a particular interpretation in areas of uncertainty'. ${ }^{77}$ Research by Braun in 2001, prior to the introduction of CD, suggests that guidance was instrumental in the development of UK PFI practice under the negotiated procedure. ${ }^{78}$ Authorities could be seen to treat this guidance as authoritative, even where it conflicted with the Commission's position. ${ }^{79}$

CD was a focus of multiple government guidance documents, ${ }^{80}$ which, rather than providing a conclusive interpretation of the law, generally aimed to assist by providing 'a framework to think in a constructive way about problems of interpretation and to make intelligent judgments' ${ }^{81}$ However, on the issue of procedure choice, the guidance was resolute: following CD's introduction, the negotiated procedure was no longer available, except in 'truly exceptional circumstances' ${ }^{82}$ This point in the OGC guidance appears to be consistent with the Commission's view. ${ }^{83}$

In general, interviewees, especially external legal advisors, played down the role of CD guidance (eg 40/45 interviewees explained how they would be prepared to depart from the guidance where it conflicted with their view of the law), tending to criticise this soft

\footnotetext{
${ }^{77}$ Arrowsmith (2006), n 29 above, 88

${ }^{78}$ Braun (2003), note 34 above, 582

${ }^{79}$ ibid

80 OGC (January 2006), n 41 above; OGC (July 2006), n 41 above; OGC/HMT (2008), n 41 above. There was also a government review of CD in 2010: HM Treasury (2010), n 65 above

81 Gordon et al (1998), n 33 above, 179

82 OGC (July 2006), n 41 above, 3; OGC/HMT (2008), n 41 above, 3.8 and 9

83 Commission, n 68 above, section 1
} 
law as overly generic. Lawyer 39 explained that ' [g]overnment guidance is there so that the Commission knows that the member state is doing things by the book and it understands the general approach, but on specific deals ... the deal is run as the [advising] law firm ... thinks the deal should be run'. However, this general perception of a limited role for the guidance was not applicable to the specific decision whether or not to procure under $\mathrm{CD}$. Here, as later accepted by government, ${ }^{84}$ a strong policy steer in the guidance shaped practice: the prominent reason for authorities choosing $C D$, as opposed to the negotiated procedure, was the clarity of the caution against use of the negotiated procedure in the guidance, 85 and, as Lawyer 7 acknowledged, this message - that the negotiated procedure is no longer available for PFI - had then simply been 'recycled' by legal advisors. As a consequence, very few interviewees could recall experiences where the negotiated procedure was chosen over CD.

This clear policy steer away from the negotiated procedure was adopted by interviewees even where it appeared that they did not agree with this aspect of the guidance, eg the 'firmness' of the guidance was a 'surprise' for six interviewees. Many interviewees also admitted that, in hindsight, the negotiated procedure had been abandoned too readily, and certain procurements, particularly private finance contracts disrupted by the financial crisis and recession, would have benefitted from the procedure's extra flexibility:

\footnotetext{
${ }^{84}$ HM Treasury (2010), n 65 above, 10 (2.36)

8519 interviewees
} 
[a]ll of us bought the Commission's message that the negotiated procedure is exceptional, but, if you look at what the legislation says, there is an argument to say that some of the grounds can be interpreted so that it is not exceptional.... We should have queried the Commission's message. (Lawyer 19)

These findings suggest that where the policy message behind legal rules is straightforward - here, that CD was to be used in place of negotiated procedure in all but the most extreme cases - authorities were generally minded to obey, even if commercially they would prefer to do things differently. Clarity is a key factor for legal compliance under Halliday's model, not only in itself but due to its impact on both the legal knowledge and legal competence of those street-level bureaucrats who must apply the law - a clear legal test is simply easier to understand and to apply, i.e. it is easier to comply with. ${ }^{86}$ Whilst here the clarity comes not from the legal rules themselves but instead from official guidance, nonetheless this clarity appears to have been a significant enough factor in the decision-making process so as to override other considerations such as business needs. ${ }^{87}$

Lack of experience and familiarity with the legal requirements may also, initially, have led procurement officers and lawyers towards taking the simplest interpretation of the law, which here would be to follow the relevant guidance. This may be equated with Kagan's findings that legal creativity requires 'time and mental effort', and for example a

\footnotetext{
${ }^{86}$ Halliday, n 1 above, chapter 6; C. Hunter, J. Bretherton, S. Halliday and S. Johnsen, 'Legal compliance in street-level bureaucracy: a study of UK housing officers' (2016) 38(1) Law and Policy 81, 88-89

${ }^{87}$ For a similar finding on simplicity and clarity in relation to a legal test in homelessness law see Hunter et al, ibid, 88-89
} 
heavy workload and external pressure for rapid decision-making can lead instead to legalistic decision-making. ${ }^{88}$ Also, procurement officers were already under significant pressure in applying a new procedure and handling a complex contract, in addition to pressure for speed due to eg organisational deadlines, leaving little time or desire to challenge clear policy guidance. Over time, procurement officers and their legal advisors would begin to appreciate the malleability of the complexity threshold (see below).

\section{The decision-making environment}

D. Risk of legal challenge

In research conducted prior to $\mathrm{CD}$, Braun relied upon economic ideas of deterrence and rational choice theory to understand behaviour, and in particular to explain the standard use of negotiated procedure for PFI. ${ }^{89}$ This view of compliance is drawn from the law and economics movement and is predicated around the idea that individuals will make rational decisions based on a cost-benefit analysis: ${ }^{90}$ an individual will comply with the law where the expected cost of non-compliance and the perceived likelihood of that cost occurring exceeds the expected benefits of non-compliance. Under this approach, the severity and likelihood of legal sanctions, then, are one key factor within the decision-

\footnotetext{
${ }^{88}$ Kagan, $\mathrm{n} 1$ above, 174

${ }^{89}$ Braun (2003), n 34 above, 595

${ }^{90}$ Becker, G. 'Crime and Punishment: An Economic Approach' (1968) 76(2) Journal of Political Economy 169, at 176. See recently C. Parker and V. Lehmann Nielsen, 'Deterrence and the impact of calculative
} thinking on business compliance with competition and consumer regulation' (2011) 56(2) Antitrust Bulletin 377 
making environment which may impact decisions. For Braun, authorities used the negotiated procedure, despite legal uncertainty over its availability, because of advantages reaped from the procedure's greater flexibility in comparison to stricter alternatives, eg enhanced value for money from negotiating. Alongside these benefits, an 'inadequate enforcement regime' meant the threat of legal challenge was widely perceived as low, and authorities could be confident that non-compliant or risky behaviour would not be the subject of sanctions. ${ }^{91}$

In 2006, when CD was introduced, guidance warned of 'the possibility of challenge if a procurement is inappropriately undertaken using the negotiated procedure', and that this could lead to 'significant delays' and may require the authority to 're-run the procurement under an appropriate procedure with significant cost and time delay implications'. ${ }^{92}$ Despite these clear warnings, the risk of legal challenge does not appear to have been a crucial factor in determining compliance. As with Braun's findings, and despite multiple amendments to strengthen the remedies system subsequent to Braun's research, ${ }^{93}$ the risk of legal challenge was widely perceived as low when deciding which

\footnotetext{
${ }^{91}$ Braun (2003), n 34 above, 587-588. The reasons behind the 'inadequate enforcement regime' was the subject of empirical investigation by Pachnou. See n 28 above; D. Pachnou, 'Bidder remedies to enforce the EC procurement rules in England and Wales' (2003) PPLR 35 and D. Pachnou, 'Bidders' use of mechanisms to enforce EC procurement law' (2005) 5 PPLR 256. See recently S. Arrowsmith and R. Craven, 'Public procurement and access to justice: a legal and empirical study of the UK system' (2016) PPLR 227 ${ }^{92}$ OGC (July 2006), n 41 above, 4

${ }^{93}$ Directive 2007/66/EC of the European Parliament and of the Council of 11 December 2007 amending Council Directives 89/665/EEC and 92/13/EEC with regard to improving the effectiveness of review procedures concerning the award of public contracts (L 335/31)
} 
procedure to use. The main reason given for this - amongst other generally applicable reasons -94 is that bidders learn about the choice of procedure early on, ie on commencement of the process, when they have invested little compared to the final tendering stage (section 000); so, even if a technical breach occurs, bidders/potential bidders will not have suffered harm, and, even if they have, it would not be sufficient to induce legal challenge: 'challenging a procurement procedure is not an academic exercise, it is a big commercial step. What would you be expecting/hoping to get out of it?' (Lawyer 30). Strict limitation periods, which run from 'when the economic operator first knew or ought to have known that the grounds for starting proceedings had arisen', 95 mean that a bidder cannot challenge the breach at a later point. The finding is consistent with quantitative research by Gelderman et al in the Netherlands, which, in relation to defence procurement, found no statistically significant relationship between the supplier remedies system and compliance with the procurement regime. ${ }^{96}$

That said, in addition to the risk of challenge by aggrieved suppliers, the OGC guidance also highlighted the potential for heightened scrutiny of procurement conducted under the negotiated procedure by the Commission: '... there will be a close examination of the use of the ... negotiated procedure for complex contracts, whereas the Commission will

\footnotetext{
94 Pachnou (2005), n 91 above, 258-259; Arrowsmith and Craven, n 91 above

95 PCR 2006, reg 47(7)

${ }^{96}$ C. Gelderman, P. Ghijsen and M. Brugman, 'Public Procurement and EU tendering directives - explaining non-compliance' (2006) 19(7) International Journal of Public Sector Management 702, 710-711. See also K. Gelderman, P. Ghijsen and J. Schoonen, 'Explaining Non-Compliance with European Union Procurement Directives: A Multidisciplinary Perspective' (2010) 48(2) Journal of Common Market Studies 243
} 
expect the use of $[\mathrm{CD}]$ ', 97 and 'authorities should be aware that the ... Commission may scrutinise any use of the negotiated procedure'. ${ }^{98}$ In reality such Commission challenges are exceedingly rare, and, even if the Commission raised an objection against the negotiated procedure's use, it would be brought against the state, not an individual authority (the decision-maker). ${ }^{99}$ These general deterrence measures, as the literature suggests, are usually limited in their ability to bring about compliance, eg in comparison to specific deterrence. ${ }^{100}$ However, this aspect of the guidance and the Commission's 'showcase' action in the Westminster Schools PFI (see above) left an impression for some interviewees, with a small number expressing wariness of Commission scrutiny. Lawyer 20 described how authorities had been 'scared off' the negotiated procedure, and, even when they had advised that negotiated procedure be used, the advice was refused due to worries about the scrutiny this would attract.

In this context, whilst the ideas of classical deterrence are informative, and it is clear that the threat of legal sanction - mainly Commission action - engendered some apprehension over any use of negotiated procedure, this does not on its own provide a fully satisfactory explanation for the high compliance rate seen in authorities here. Further reasons for the low risk approach taken by the authorities must be found elsewhere.

\section{Commercial pressures}

\footnotetext{
97 OGC (January 2006), n 41 above, 3 ${ }^{98}$ OGC/HMT (2008), n 41 above, 10. And, see also OGC (July 2006), n 41 above, 4 
A key external factor in the decision making process was commercial pressure, which could push authorities towards a higher risk approach. The high take-up of CD is in fact because it was used for many contracts that previously would be procured under the restricted procedure, eg more straightforward, non-PFI contracts where it is less clear cut that the complexity threshold is met, ${ }^{101}$ and research by UK government suggests widespread inappropriate use of CD (29\% out of a sample of 210 CD procurements). ${ }^{102}$ The behaviour is tactical: the risk of challenge at this stage is low (to make procedure choice 'realistically ... an open choice' (Lawyer 23)) and CD's flexibility is commercially attractive. So, even if a contract is not 'particularly complex', choosing CD is advantageous: by using CD over the restricted procedure, the more flexible CD is able to accommodate any developments in an authority's requirements (eg a contract may turn out to be more complex than initially envisaged and negotiation wanted):

what I say to clients is, 'if you are going to have to negotiate, use [CD] because, if you negotiate in a restricted [procedure], it is very obvious and incredibly risky'. I can't be bothered going into the definition of a particularly complex contract with them because it is just not relevant in practice. (Lawyer 13)

\footnotetext{
${ }^{101}$ HM Treasury (2010), n 65 above, 11

102 Cabinet Office, Accelerating government procurement (2010), 12
} 
The ambiguity of the provision enables this interpretative strategy (arguable gaming of the regulatory system),103 so that, even if a project's complexity was questionable, according to Lawyer 20, 'as legal advisors, if need be, it is our role to find the necessary complexity'. Where the commercial benefits of CD were perceived to be strong enough and were combined with a high level of legal knowledge and competence, this could at times also inspire a more critical approach to the soft law discussed above, as exemplified by Lawyer 19:

The reality is that discussions are almost always productive, always leading you to improve the terms of the deal etc. and designing into the specificity of the case. My interpretation is considerably more generous than that of the Commission. A strict interpretation may lead you to say that a lot of these contracts are not complex in the way that the Commission understands it. I would say, 'so what?'. We should interpret it more loosely.

This is the same Lawyer 19 (quoted above in section 000) that expressed regret for failing to dispute a narrow interpretation of negotiated procedure's availability. However, for this decision - choosing CD over the restricted procedure - their position within Halliday's model is different. Here, the law was weaker, with less clarificatory guidance on this point, and there was a pressing commercial argument behind CD's use because of the greater scope for dialogue. The interviewee was therefore prepared to exercise legal creativity.

\footnotetext{
103 See D. McBarnet and C. Whelan, 'The elusive spirit of the law: formalism and the struggle for legal control' (1991) 54(6) MLR 848 (discussed by Black, n 3 above, 13)
} 
Despite wide use of $\mathrm{CD}$, as time passed the procedure garnered a negative image: it became associated with bureaucratic meetings, and lengthy and costly procurement. ${ }^{104}$ This led to a move corresponding with legal creativity, with 21 interviewees describing how they would purposively avoid CD regardless of a contract's complexity. The authority would instead procure under different procedures, or purposely structure the arrangement to take it outside the scope of the PCR 2006, eg a services concession or development agreement. The latter option also had the benefit of allowing more flexible negotiations throughout the process, avoiding CD's legal restrictions on work that could be done with the preferred bidder (considered in the next section). As regards different procedures, with the negotiated procedure regarded as off-limits, the restricted procedure was the preferred alternative and was hoped to be attractive to the market: although unsuitable for genuinely complex contracts due to strict legal limits on the room for dialogue/negotiations during the process, it had a stronger association with efficient procurement, which, it was intended, would lead to greater interest in contracts: ' $[t]$ hey were just so keen to avoid the perception of bureaucracy and reluctant bidders; it is dangerous' (Lawyer 21). In this regard, the market, or perceptions of what would be attractive to potential suppliers, is significant in steering decision-making in PFI, and this message found its way into 'practice-informed' guidance. ${ }^{105}$ Corresponding with this, the main sanction open to a bidder aggrieved by the decision to use CD rather than the restricted procedure was, rather than litigation, seen as commercial: '[a] bidder is not going to say to an authority, it is illegal that you are using [CD] because this is not a

\footnotetext{
${ }^{104}$ HM Treasury (2010), n 65 above, 14, para 3.11

105 OGC/HMT (2008), n 41 above, 13-17
} 
complex contract. The bidder is going to say, I don't want to bid for this because if procured under $[C D]$ it is going to be too expensive. It is not going to ... challenge the decision' (Lawyer 13).

As frequently occurs, experience from practice eventually fed up to national policy level. In view of dissatisfaction with CD - in particular flowing from the 2007-08 financial crisis - soon after the Conservative-Liberal Democrat Coalition Government was formed in 2010, in line with its lean procurement agenda, ${ }^{106}$ guidance changed tack pushing the restricted procedure, and with a presumption against use of CD. ${ }^{107}$

To summarise, in accordance with Halliday's framework, external pressures, chiefly the market, carried increased weight the more uncertainty there was over the legally correct approach. For the decision whether to use CD or the negotiated procedure, soft law provided sufficient clarity, showing EU and UK regulators together in the promotion of $\mathrm{CD}$, and legal compliance was strong. However, because negotiations were commercially attractive, the lack of clarity over the complexity threshold meant that CD came to be used excessively, as a substitute for the restricted procedure where the complexity of contracts was questionable. As time passed, in some situations, the market turned against CD, and thus some complex contracts were procured under the unsuited restricted procedure, despite the fact that such contracts would almost inevitably require negotiations prohibited under the restricted procedure, giving the choice a high level of legal risk. The

\footnotetext{
106 Cabinet Office (2010), n 65 above

107 Cabinet Office, Procurement policy note - procurement supporting growth: supporting material for departments (May 2012)
} 
lack of clarity in the law was key to enabling these various responses. The message of the legal rules was obscured, not simply due to the imprecise and inconsistent wording of the text, but because of more fundamental disagreements. At its core, the EU legal framework is in place to prevent trade barriers and the regime aims to ensure certain levels of competition in order to support this aim. ${ }^{108}$ There would be a mismatch if a strict application meant that CD's use risked putting bidders off, reducing the field. Competition would be undermined for an individual authority. Adding to this, the legal rules - seen as inefficient by some - would be at odds with the corporate-like ethos cultivated across the public sector in the UK, eg associated with the New Public Management. ${ }^{109}$ So, even for those interviewees with normally high levels of legal competence, such as lawyers, it may have been difficult to identify the 'correct' approach. Nor did high levels of legal conscientiousness necessarily help; even when interviewees had a strong commitment to the law and wished to comply, there was no clear solution as to what the 'right' approach was in these circumstances given the competing demands. Here, then, the normative power of the legal rules was weakened considerably, and, if the market was seen to apply pressure one way or the other - for the use of CD over a less flexible procedure or against the use of $\mathrm{CD}$, it is unsurprising that such pressure had traction.

\section{B. Grey area two: negotiation with the preferred bidder}

\section{Background}

\footnotetext{
108 Arrowsmith, n 9 above

${ }^{109}$ C. Hood, 'The "new public management" in the 1980s: variations on a theme' (1995) 20(2-3) Accounting, Organizations and Society 93
} 
PFI procurement under the negotiated procedure enabled swift reduction of bidder numbers and early appointment of a preferred bidder. This can be attractive for bidders and authorities as costs are minimised, and, in particular, only one bidder (and its debt funders) need incur the work and (hefty) costs in pulling the deal together. However, despite these commercial attractions, the (potentially substantial) negotiations that would take place when just one bidder was left in the running were, for the Commission in particular, problematic. ${ }^{110}$

The legal rules on CD seek to curb negotiations with just the preferred bidder so as to maintain competition until later on in the process. Following close of the dialogue stage, the authority must invite remaining bidders to submit final tenders, which must 'contain $[\ldots]$ all the elements required and necessary for the performance of the project'. ${ }^{111}$ The rules also express some compromise, recognising that with such complex transactions it may not be practicable to finalise all details before choosing a winner and, for various reasons, amendments may need to be made to a preferred bidder's tender. ${ }^{112}$ Following the appointment of a preferred bidder there is room for clarification of aspects of the tender or confirmation of commitments contained in the tender 'provided this does not have the effect of modifying substantial aspects ... and does not risk distorting competition or causing discrimination'.113 The drafting of these new rules again gives rise

\footnotetext{
110 Arrowsmith, $\mathrm{n} 37$ above

111 Public Sector Directive 2004, art 29(6); PCR 2006, reg 18(25)(b)

${ }^{112}$ Arrowsmith, n 10 above, 8-79-8-83; S. Arrowsmith and S. Treumer, n 11 above, 5.7.3; C. Kennedy-Loest, 'What can be done at the preferred bidder stage in competitive dialogue' (2006) 15 PPLR 316

113 Public Sector Directive 2004, art 29(7); PCR 2006, reg 18(28)
} 
to important legal grey areas, and it is unclear to what extent PFI procurement practice under the negotiated procedure, which developed for commercially valid reasons (see section 000 above), is circumscribed under CD. Specifically, there is uncertainty over the degree to which consideration or finalisation of matters may be delayed until after appointment of a preferred bidder - how final must final tenders be? - and the scope for changes to tenders.

\section{Clarity of the law}

For this second grey area, the lack of clarity in the legal regime was not remedied with soft law, and so levels of legal knowledge and competence were correspondingly lower at this point than for the first grey area. OGC was reluctant to adopt a firm position in this controversial area, arguing that certainty was not possible without legal precedents from court judgments. ${ }^{114}$ This may explain why the guidance was seen by interviewees as a helpful starting point, but, due to its generic nature, not influential in decision-making. ${ }^{115}$ However, guidance issued later on in 2008 , which was informed by survey and interview data, did represent a more pragmatic interpretation of the legal rules, made particularly necessary in view of the financial crisis. This commercially relevant guidance, which also presented a list of subjects that it might be appropriate to leave to be resolved with just the preferred bidder, was noted as helpful, providing 'comfort'. ${ }^{116}$

\footnotetext{
114 OGC/HMT (2008), n 41 above, 30, 5.5.2

115 40/45 interviewees

11620 interviewees
} 
In line with the framework provided by the guidance, interviewees often avoided answering questions on the precise legal scope for changes at the preferred bidder stage; many preferred to emphasise the indeterminacy of the law and practical considerations, and would outline differing degrees of change and the level of legal risk attaching to these, or would present the answer as a position they would be/could become comfortable with in order to support an argument for changes. This is because any change, however minor, brings some degree of risk. ${ }^{117}$ In the words of Lawyer 39, '... clients will be told that there is a legal risk attaching to any change that you do; then it is just a question of how much risk the authority wants to run'. There was a spectrum of changes - ranging from low risk to high risk - which, in the language of practitioners, authorities could 'take a view on':

if what you are tweaking is stuff that is manifestly not changing anything which would count in your evaluation ... that is something which at least in theory you are probably safe doing under any procedure.... If it would affect the decision, that is really dodgy. ... [W] $[\mathrm{W}$ ere ... the winner's offer looks even better then arguably that is better than one that makes the winner's offer look worse. But ... there is always a risk that the losing bidder will say, 'while they have improved by five percent, had you given me the chance I would have improved mine by $10 \%$ and caught up'. ... [A]nything that changes evaluation marks at all is to be inherently avoided; it is not that it is illegal, it is just risky. Then there is the problem of changing a lot of stuff that does not change evaluation individually, but when

11721 interviewees 
considered altogether there is a risk someone is going to argue successfully in court that it would have. (Lawyer 12)

An analysis of the wording of the law was not employed to set the boundaries of the discretion, rather, for external legal advisors, the law was determined by reference to underlying general principles (eg proportionality) and scope for change in comparison areas, like changes to concluded contracts:

I doubt there is any great significance in these words; I mean, one can stare at them and their precise boundaries are not going to become apparent through semantic scrutiny. It is going to be a matter of what a court thinks is reasonable. (Lawyer 5)

In comparison to the first grey area, here the lack of clarity in the law was more severe, with little detailed practical guidance to fill the gap in knowledge until 2008. Very broad uncertainty, such as this is more likely to lead to creative compliance, or a high risk approach. ${ }^{118}$ Here, as per the Halliday model, the lack of clarity provided the necessary freedom for authorities to interpret/apply the law in a manner consistent with the external pressures on them, including commercial and financial concerns, and, even where a technical breach might have been committed, solace could often be found in the justification that such actions were compatible with general principles of the regulation. The legal uncertainty meant that the regulatory regime became a less important normative pressure than other relevant factors.

118 Craswell and Calfee (1986), n 64 above, 280 


\section{The decision-making environment}

D. Risk of legal challenge

At this point in the process, the threat of sanctions also appeared to be a greater factor on decision-making. Theoretically, the risk of a bidder challenging for breach of the EU/UK procurement rules is at its highest at this late stage in the process, following identification of the preferred bidder. This is because, as explained in interviews, bidders will only be inclined to challenge when they lose out on a contract, and, as costs incurred in taking part in the process rise over the course of a procurement, legal challenge becomes more justifiable. ${ }^{119}$ The larger the project, the greater the loss:

a really major PFI, eg in the billions of pounds, bidders will have invested in bid costs of anywhere between five million and 15 million pounds. That is an awful lot at stake. The potential for challenge in these big procurements, particularly as there will not be another big hospital PFI just around the corner, it is more likely. (Lawyer 27)

The reaction of interviewees to the more prominent challenge risk at this stage provided some support for classical deterrence theory. Where a change is needed at this stage, in deciding between different options, 27 interviewees explained decision-making in terms of a balancing exercise between different factors, such as the severity of the breach and

${ }^{119}$ See Pachnou (2005), n 91 above; and Arrowsmith and Craven, n 91 above 
likelihood of (successful) challenge, and the cost, delay and risk of alternative courses of action (see below), summed up by Lawyer 5 as 'the level of legal risk multiplied by the level of practical risk that someone's going to challenge'. In this regard, Lawyer 30 stated:

whether to allow changes ..., will ... come down to a common sense decision: a balance. You have to be commercial ... but also play by the rules. ... [I]t will be a case of pragmatism versus technical correctness; we will not just outline a problem for the umpteenth time. ... You must take a pragmatic approach depending upon what you think you can get away with. We will not advise upon a breach of the rules, but it is never as straightforward as that. Where the scope for change is unclear, we want to be helpful, not obstructive.

The threat of sanctions generally remained too weak to overpower other pressures on decision-makers and lead to a low-risk approach. In particular, interviewees pointed out that challenge risk is not simply measured in the abstract: an assessment of the individual circumstances of the case will be crucial. ${ }^{120}$ The risk of challenge needs to be perceived as real for a strong impact on decision-making. For example, in the words of Lawyer 6, much would depend on 'how disgruntled the unsuccessful bidder was. Are they chomping at the bit and jumping up and down, or are they actually quite okay with it?', and, according to Lawyer 27, 'you get to know bidders as you are going through and can often gauge the real likelihood of challenge'.

12012 interviewees (others not commenting) 
Where a substantial change occurs at preferred bidder stage, the only compliant option may be to start the procurement again with a fresh contract notice (and even then there is a risk that bidders may sue for wasted bid costs). However, at this late stage this was unthinkable:121 no interviewees had experience of such an abandonment after the preferred bidder had been appointed. The main reason given for this was the huge cost involved for authorities and bidders, which overrides possible detriment resulting from possible legal challenge. Other reasons included the need for the authority to keep to timescales, and embarrassment and reputational damage for the authority and for individuals, which may mean bidders think twice about taking part in future procurements.

[w] will rarely advise upon going back or restarting a procedure at this stage, just because of the costs involved and also because these projects have to be delivered: people are expecting a new hospital or a new fire station. (Lawyer 24)

Although, for many interviewees, low risk behaviour was abandoned or would be abandoned in situations in which substantial changes were needed at the preferred bidder stage, for some, especially those authorities intimidated by a real threat of legal challenge, different practices were adopted to avoid a restart. For example, an authority might rewind the procurement, eg rerun the final tendering stage, bringing rejected

\footnotetext{
${ }^{121}$ This position was expressed by 13 interviewees. Nevertheless, as stated by five interviewees, this option will be on the table where the change is so significant that a different set of bidders would have sought to participate in the procurement process had they known at the outset or where rewinding short of restarting the process is considered not possible
} 
bidders back into the process, or even going further back and reopening the dialogue stage (though it is not clear whether reopening dialogue is legally permissible). ${ }^{122}$ From a cost and time perspective, for both authorities and bidders this is more attractive than a complete restart. Also, whilst it does not ensure legal compliance, and actually gives rise to practical and legal complications of its own (eg concerning confidentiality and equal treatment), ${ }^{123}$ the risk of challenge may be kept in check, as aggrieved bidders may be brought back into the competition and given a further opportunity to bid for the contract.

Similarly, continuing practice developed pre-CD under the negotiated procedure, five interviewees spoke about how, to minimise legal risk should negotiations with the preferred bidder breakdown, the second place bidder would be given reserve bidder status, so that an element of competition is maintained in the late stages. Again, the practice may not be legally compliant and runs counter to OGC guidance, ${ }^{124}$ and, as above, practical and legal difficulties surround the way in which a reserve bidder may be brought back into a process.

According to Policymaker 3:

it is a case of balancing the risks of what you do and what you do not do. Sometimes the risk of not doing anything can sometimes outweigh the risk of

\footnotetext{
122 Nine interviewees had experience of this

12315 interviewees

${ }^{124}$ OGC (January 2006), n 41 above, 6 (10.1)
} 
doing something. You can get yourself in a situation where there is no risk free solution ... You just have to balance them. (Policymaker 3)

Further strategies to minimise legal risk at the preferred bidder stage developed over time, including requiring a higher degree of bid development before the close of dialogue:

there is a drive to get to commercial certainty when ... still in dialogue due to the uncertainty about what is and is not permissible post-closure of dialogue. (Lawyer 10)

Linked to this, a practice of holding a 'dry run' final tendering stage, enabling the contracting authority to iron out any problems with tenders during the dialogue stage whilst there is still flexibility in the procedure to do so was explained to have become widespread. This approach originated for non-legal reasons. It was a requirement of organisations responsible for specific PFI programs, like Partnerships for Schools, ${ }^{125}$ to provide assurance over the financial viability of projects. The practice however found favour with some authorities described as risk averse:

it will very much depend upon the client's risk appetite. If you get a nervous client who wants to follow the letter of the law, they will want to have everything done during dialogue, and some of them, I am sure you will or have come across this, have ... a dummy run ..., so that they are confident that the bids they get back will contain all the elements necessary. Other clients are a bit more feisty and

${ }^{125}$ www.partnershipsforschools.org.uk (last accessed 11 July 2017) 
prepared to accept a bit more flexibility at preferred bidder stage and will not be terribly bothered about that. They will not have hammered down all points; there will be quite a lot of square brackets and things like that; so, it will very much depend on a client's risk appetite. (Lawyer 13)

\section{Commercial considerations}

In the latter stages of $\mathrm{CD}$, and the determination of how much room for manoeuvre there is for authorities, unlike the approach for grey area one, commercial expectations and resource constraints overwhelmingly prevailed and interviewees, even if they agreed with a strict interpretation of the legal rules (seemingly favoured by the Commission), ${ }^{126}$ applied the rules in a flexible manner, whereby matters (eg relating to design and commercial and legal terms) would be left to be dealt with/finalised when there was just one bidder left in the process. The way in which a strict interpretation stood counter to market norms was the main driver for this practice:

tenders should be ... completely final ... but no one is going to fully negotiate a full legal agreement and spend a huge amount of time and money on lawyers' fees getting the agreement in a form where they are ready to sign if they are not the preferred bidder. So, it is all very well saying that only 'clarification' is allowed and that is fine for commercial principle, but actually in terms of negotiating the

\footnotetext{
126 This emphasises restrictive wording, 'clarifying' and 'confirming', and expressly rules out negotiations with one bidder, as 'such negotiations were proposed and rejected by the EU legislative process' (Commission, n 68 above, 10 (3.3))
} 
legal documentation, getting all that done, there is still going to be some toing and froing at preferred bidder stage. ... [I]t just does not make sense for [bidders in dialogue] to spend thousands of pounds ... negotiating an agreement you are never going to use. (Lawyer 4)

Even for interviewees favouring an interpretation of the legal rules that afforded authorities reasonable flexibility to work with the preferred bidder (ie falling back on general principles like proportionality), the interpretation was adopted with commercial reality, and the inherent complexity of the contracts, in mind:127 in particular, the substantial resources needed to bring negotiations to a close, which bidders are reluctant to do at risk; and the limited involvement of debt funders, which will be reluctant to subscribe to firm undertakings, and will look to hold off detailed due diligence, until the client has certainty of success (ie preferred bidder status):

[a] narrow interpretation ... is counterproductive. You have complex contracts that need discussion and limiting people, front loading the whole system and asking bidders that do not stand a chance to spend millions of pounds participating in a long dialogue ... Our perspective is different to the Commission's perspective. They say just follow the letter. Our view is concerned with discrimination and transparency; provided you respect transparency and fairness you are okay. (Lawyer 19)

\footnotetext{
127 There were other interviewees, however, who simply recognised the requirement as uncertain and could not comment on its interpretation (7/35)
} 
For some interviewees, ${ }^{128}$ therefore, the introduction of CD had brought about few, if any, changes: '[w]e have not seen much difference maybe because people do what they are used to doing' (Lawyer 18). Most, however, recognised that despite obstacles to achieving sufficiently complete final tenders by close of dialogue and perceived full compliance, final tenders were more final than had they used to be:129

[d]o not expect to close the dialogue and have six months of negotiations. The substance of the tender must be there. You need to bring [the dialogue] to a fuller conclusion than under the negotiated procedure, but there is a good room for manoeuvre. (Lawyer 19)

In addition, there was a less prevalent, but noteworthy, cautious approach to the application of the legal rules. ${ }^{130}$ This may be explained due to the way in which commercial pressures often featured as part of the calculation conducted by interviewees in light of the risk of legal challenge (see below), with some opting for a low-risk approach legally but being critical of the impact this had on the commercial elements of the process:

[the risk of challenge] makes [authorities] focus on compliance rather than getting the best result. It is a bit of tightrope. What you are trying to do is stop the client falling off one side - getting sued - but falling off the other side means you do not get the bids you want. (Lawyer 41)

\footnotetext{
128 2/25 interviewees

129 10/25 interviewees

130 17/47 interviewees
} 
CD's introduction had some impact, therefore, in changing the behaviour of decisionmakers and countering commercial behaviour, but there was overall a much more clearly flexible approach than can be seen for grey area one. This is to be expected. Compliance tends to be problematic when regulation conflicts with existing market or social norms, ${ }^{131}$ and this was especially the case here where benefits to authorities from adopting PFI procurement practice in line with the new rules was not readily apparent, and may even, in some instances, be seen to contradict other domestic policy objectives, like value for money. The law - suffering from a lack of clarity - was weak in the face of strong commercial and practical pressures; however, the risk of challenge, in particular, would encourage some reform to PFI procurement practice.

The compatibility of the EU rules with the commercial pressures on authorities to minimise procurement costs and get a good deal was not always clear, potentially meaning conflict between EU law and domestic policy. Some interviewees responded to this with a flexible, legally creative approach. Authorities utilised legal uncertainty to insist upon an interpretation most favourable to their situation at a particular point, eg adopting a narrow approach to the restriction on changes to tenders to resist a change that would, from the authority's perspective, worsen the deal, and a flexible interpretation when the authority wanted to make the change: ${ }^{132}$ '[v]ery often the procurement rules are used as a sort of fig leaf to cover the authority's commercial

\footnotetext{
131 OECD, Assuring environmental compliance: a toolkit for building better environmental inspectors in
} Eastern European, Caucasus and Central Asia (2005), 28

132 11/20. See Black, n 3 above, 13 
position: it is easier for someone to say we cannot do this for procurement law reasons rather than just we do not want to do that' (Lawyer 13). The commercial deal was generally recognised to be most important in decision-making - with the legal rules or legal risk secondary: 'it is about the commercial position. [Legal] risk usually only comes into it if you want an added reason to refuse the change' (Lawyer 6). However, the position changes as the preferred bidder stage advances: an authority's bargaining position weakens. It will have invested considerable resources, will have committed itself to one bid, and will want to avoid delay (and extra costs) and see the project come to fruition within timescales. This makes it difficult for an authority to hold to a particular interpretation of the rules and ward of (bidder/bank-introduced) changes at a late stage:

it is a very different situation where two months post-appointment of preferred bidder when a credit committee comes along with things they want to change. The dynamics are totally different; the bidder is in the dominant position. Do you want your project or not? There are timescales, promises that a contract will be signed by $\mathrm{X}$ date. (Lawyer 41)

\section{Exceptional circumstances}

As regards the decision-making environment, market and financial concerns were more prominent at this point than for grey area one. In particular, a long-standing difficulty in PFI procurement has been the involvement of bidders' debt funders who can be reluctant to incur significant costs, eg the costs of detailed due diligence, until after the client has assurance of preferred bidder status: '[i]n the good/bad old days, you used to lie until you got your bank along. You relied on your bank to say how it is. The bank would come in 
at preferred bidder and say, "I like the project but I cannot do this, this and this". After several meetings, a lot of shouting, and a few tears, the bank would get its way' (Lawyer 17). In the closing stages of a procurement process, funders frequently find themselves in a strong position, and may be able to dictate revised terms more favourable to them: 'If the bank does not like it ... the bank will just say, "if you do not want this money do not have the money". What will the authority say then? It will say, 'I would rather have the money than stick to the rules"' (Lawyer 17).

Due to the reliance of PFI on private finance, the 2007-08 financial crisis had a dramatic impact on PFI procurement, circumstances that exacerbated the above problems posed by funders, increasing the stress on the legal framework - as recognised in 22 interviews: 'Anyone who has actually closed a project in the last two years has done a fantastic job, but from a procurement law perspective, they will have had to cut a few corners' (Lawyer 17). Inevitably, during this period, banks, because of the uncertain financial markets, refused to lend or sought substantial changes to the terms upon which funding was available, even for procurements on the verge of contract close. Interviewees reported numerous other difficulties resulting from the financial crisis, such as members of a preferred bidder consortium going insolvent.

The UK government recognised that, to enable procurement affected by the financial crisis, a strict approach to the legal rules was not tenable. For example, in March 2009, the Treasury Infrastructure Finance Unit was established, which - stretching the interpretation of changes that are permissible at the preferred bidder stage - was available to step in to lend on the same terms as commercial funders where sufficient 
private funding was no longer forthcoming. ${ }^{133}$ Also, 2008 OGC guidance was phrased in more pragmatic terms: authorities would need to 'balance the legal requirements with the need to achieve contract signature while operating in a world where change[s] can occur'.134 Policymaker 3 reflected on this:

the recession and the breakdown of the banking market posed real issues. ... [I]t suggested ... a strict application of these EU rules simply was not going to work. A complex procurement often takes two years or more and if part of the way through that period the market crashes sometimes the only way you can get the project away is by doing something that had not necessarily been foreseen in the original OJEU. ... [0]ne of the things that happened is the public sector making financial contributions to projects ... A technical interpretation of the rules might have caused difficulty but actually abandoning the whole thing and starting again was not of any practical benefit to anyone ... You are still in the same market; you are still doing the same thing; it is just you have started again, but people have wasted ... bid costs. ... You try to take a practical approach bearing in mind the principles of fairness, equality and transparency. There were a number of projects where changes were made part way through the process, but there was pretty much no alternative other than abandon the procurement.

\footnotetext{
${ }^{133}$ HM Treasury, Treasury lending to PFI projects and the Treasury's Infrastructure Finance Unit (5 May 2009), available at http://webarchive.nationalarchives.gov.uk/+/http:/www.hm-
} 
There is no exception in the legal rules to accommodate substantial changes, like those highlighted above, at the preferred bidder stage. However, the financial crisis brought into question the logic of the legal rules, and rendered their strict application a nonsense. ${ }^{135}$ This type of phenomenon has been observed in other areas of law, eg member states, the UK especially, hastily acted to prop up failing banks with billions of pounds of finance and seemingly minimal regard for Treaty obligations for ex ante Commission approval of this state aid. ${ }^{136}$ Legal compliance took a back seat in what was arguably a (so called) state of exception,137 and the Commission adopted a pragmatic response to cater for this extreme occurrence. ${ }^{138}$ Though the financial crisis also provoked some extraordinary (soft law) measures from the Commission in the procurement field, ${ }^{139}$ unlike the Commission's approval of 'unlawful' state aid, no Commission reassurances about a relaxation of the legal framework for CD procurements affected by the financial crisis were forthcoming. No Commission enforcement took place, however.

The financial crisis can be seen to have caused cleavage between the two sovereigns, EU and UK, in play. Indeed, in certain cases, internal market norms - the benefits of which to

\footnotetext{
135 W. Davies, 'When is a market not a market?: "exemption", "externality" and "exception" in the case of European state aid rules' (2013) 30(2) Theory, Culture and Society 32

136 TFEU, Articles 107-109. See Davies, ibid

137 G. Agamben, State of exception (University of Chicago Press, 2005)

138 Discussed in Chalmers et al, European Union law: cases and materials (Cambridge: CUP, 3 ${ }^{\text {rd }}$ ed, 2014), 1082-1085
}

${ }^{139}$ Commission, Public procurement: Commission recognizes need for accelerated procurement procedure (IP/08/2040, Brussels, 19 December 2008) 
individual authorities (an internal market in public procurement) are not readily apparent - would be seen as incompatible with more pressing local objectives (notably efficiency and value for money), especially where the legal rules were seen to be delaying or obstructing public investment. There was little clarity over the response required, and it is no surprise that the demands of a separate normative order - the market - would have particular pull. Also, in a similar vein to the balance sought between compliance with the technical procedural requirements and 'competition', discussed in section 000, as a result of the financial crisis uncertainty arose from perceptions of conflict between a correct application of the rules in this situation ('the letter of the law') and the very fundamentals of the regulation - 'the spirit of the law' - eg notions of fairness, as set out by Lawyer 40 (whose comment also supports the generally high levels of legal conscientiousness found): 'Particularly over the last few years, you have seen people with the best will in the world want to comply but with something like the financial crisis ... nobody could have predicted that. It would be unfair to say authorities couldn't then make amendments to take account of that'. So, with no viable option other than to accept a (substantial) change at the preferred bidder stage, heightened uncertainty helped the market to prevail and led to what might in other situations be deemed flagrant violations of the law.

There are also signs that in certain cases this state of exception was accepted by disgruntled, losing bidders that might otherwise have sued. Lawyer 10, for example, spoke about how unsuccessful bidders were prepared to accept a change where the preferred bidder's lender withdrew due to problems caused by the financial crisis: 
The other two bidders did not challenge. ... We had a discussion with them to say, 'look, you are going to tell us that you can stand over your bid as it is, but we know for a fact that your funder is not prepared to stand over your terms'. I do not want you to think it was a decision taken over night; it was a complicated process involving some of the highest levels of government. We looked at it and did an awful lot of due diligence from a financial perspective to see if it would be possible to just instead move to bidder number two for example. It was not.

Despite signals from UK government, there were few guarantees over the existence of a state of exception. A great deal of uncertainty surrounded the degree to which legality had been (temporarily) suspended, if it had been, and whether or not legal enforcement would take place. Due to the complicated nature of decision-making at this stage, and particularly in situations where time was not critical, another response was indecision and procurements were frozen. For example, Procurement Officer 14 detailed the state of an ongoing CD procurement, greatly affected by the financial crisis, where the preferred bidder could no longer commit to deliver the project to the scale set out in the winning tender. The preferred bidder had been in place for 18 months. The authority was in a bind. It did not want to reopen the competition because of the 'costs, time and resources that would have been wasted' and because it liked the preferred bidder's offer and was convinced that, despite the changes, the offer could not be bettered. It also did not want to conclude the contract due to the risk of challenge and because, in time, the bidder might recover sufficiently to deliver the project to the scale offered originally.

\section{A. Conclusion}


The Halliday model has proved a valuable tool for making sense of the 'complicated and fragmented' nature of approaches to compliance with the legal regulation on PFI procurement, a very different setting to the one in which the model was crafted. In contrast to Halliday, commercial and financial pressures were a dominant force in the decision-making environment. However, decision-making did not depend solely on commercial pressure, despite the great strength of that pressure during and immediately after the financial crisis. No single factor could on its own account for the different responses of the interviewees to the two grey areas. Rather, the data reveals the intricate interaction of elements making up the 'social world of government administration', specifically legal conscientiousness on the part of decision-makers, clarity and certainty in the law itself, and competition between law and other normative orders in the decision-making environment. Overall, the findings illustrate nicely Halliday's reflection that convergence and competition between legality and other normative influences depends heavily on context, and will vary within the same context across time. ${ }^{140}$

Why, then, was market pressure so crucial in this particular context? The strength of this factor is not explained by deficiencies in decision-maker competence or conscientiousness: the data suggests that both procurement officers and lawyers, on the whole, attempted to comply with all the legal requirements as far as possible, displaying generally high levels of both competence and conscientiousness. For example, as seen in the discussion on grey area two, efforts were made to counteract otherwise high-risk decision-making, such as by ironing out the need for preferred bidder negotiations through staging a dry-run final tendering stage before closing the dialogue; though, at the

${ }^{140}$ Halliday, n 1 above, 88 
same time, the need to manage challenge risk was also an important factor behind the adoption of such practices.

Instead, the main distinguishing factors between the decisions came down to the clarity of the law, and competition between the demands of law and the demands of alternative normative systems. It was generally easier given the structure of the regulation and the commercial and financial pressures on the decision-makers for a low-risk approach to be taken at grey area one, ie the choice between $\mathrm{CD}$ and the negotiated procedure. The initial choice of whether to use CD or the negotiated procedure was a simple binary choice, with relatively clear legal requirements given the policy guidance, and did not generally conflict greatly with many external pressures such that the decision-makers felt uncomfortable with its application. These factors meant the law was strong in the decision-making environment, making high compliance rates more likely. ${ }^{141}$ It was seen that for some contracts, where the decision was between the restricted procedure and $\mathrm{CD}$, the decision was often made to use CD even though these contracts might fall short of the procedure's complexity requirement. The dynamic here was different. There was less clarity on the issue, and authorities perceived that they could reap commercial benefits from such decisions. As time passed, the dynamic between elements varied further. CD garnered a negative image, and some authorities started to avoid it, preferring a different procedure (the restricted procedure). The decision to reject CD was because, resulting from a lack of clarity in the law, the law was weak (relative to the market), when business (potential bidders) took against CD, eg because of costs associated with it.

${ }^{141}$ Hunter et al, n 86 above, 88 
For the second grey area, in particular, legal (un)certainty was crucial in the analysis. A lack of clarity over what was required for legal compliance enabled non-legal factors the market - to have greater sway, and drive for a commercial interpretation and application of law. The legal uncertainty did not just derive from the regulatory texts, eg inconsistent provisions, a greater range of potential responses to the legal requirements as regards the correct level of negotiation, and less clear official guidance on the preferred approach, but the analysis highlighted important further causes of legal uncertainty. There was huge pressure from the market for a commercial interpretation of the legal requirement for complete final tenders, in line with familiar PFI practice under the negotiated procedure. This was restrained, to an extent, by the threat that individual suppliers, disgruntled because they had lost out on the contract, might sue. Authorities could nevertheless reassure themselves that they were complying with the legal requirements, despite a high-risk approach, by arguing that their interpretation conformed with underlying principles. A perceived mismatch between the letter and spirit of the regulation generated sufficient legal uncertainty to facilitate a market-driven approach to interpretation and application of the law. The financial crisis also led to decisions that were perceived as violating the legal rules. 'Substantial' changes occurred which legal rules specifically disallowed, with the significant practical and commercial reasons behind these violations garnering more traction because of legal uncertainty at the time. This uncertainty was compounded by the clash between two sovereign powers: whilst there was no offer to suspend full operation of the legal rules from the EU, arguably, this was UK government's position, which was keen to ensure that public investment went ahead without undue cost and delay. The article characterised the period as a state of exception: the normative order of law was temporarily suspended. However, the law was not completely ignored. Indecision was also a common response 
in this period. Aspects of the decision-making environment, like a very real prospect of challenge, were still sufficient to represent a counterweight to the pressure to violate the law. This can be explained by the severe doubts over the possibility of any relaxation of the legal framework.

Ultimately, this paper has shown that considering administrative compliance in the context of a commercial setting such as public procurement can provide a valuable addition to our current understanding. In such a setting, the importance of normative pressures outside the legal regime - particularly market pressures - is enhanced. The desire to comply, then, must be balanced against that pressure and it can be seen from this research that the key determinative factor in which pressure prevailed was the clarity and certainty of the relevant legal rules. 